\title{
DETERMINATION OF THIN-LAYER SOLAR DRYING KINETICS OF CASSAVA NOODLES (TAPIOCA)
}

\author{
N.C. Ezeanya ${ }^{1}$, C.C. Egwuonwu ${ }^{2}$, A.B Istifanus ${ }^{3}$, V.C Okafor ${ }^{4}$ \\ ${ }^{I}$ Department of Agricultural and Bioresources Engineering, Federal University of Technology, Owerri, Nigeria \\ ${ }^{2}$ Department of Agricultural and Bioresources Engineering, Federal University of Technology, Owerri, Nigeria \\ ${ }^{3}$ Department of Agricultural and Bio-Environmental Engineering, Taraba State College of Agriculture, Jalingo, \\ Nigeria \\ ${ }^{4}$ Department of Agricultural and Bioresources Engineering, Federal University of Technology, Owerri, Nigeria
}

\begin{abstract}
The aim of this study is to determine the thin-layer drying kinetics of cassava noodles (tapioca) using a solar dryer. To achieve this, an integral type forced convection solar dryer, equipped with rock storage, was developed. Drying kinetics of tapioca were determined using the solar dryer. The treatments in the experiment comprise of air flow velocities $(V)$ of $1.5,2.5$, and $3.5 \mathrm{~m} / \mathrm{s}$; and drying layer thicknesses (B) of 0.48 and $0.72 \mathrm{~cm}$. Tapioca samples were dried from an average initial moisture content of $297 \%$ (dry basis) to $9.8 \%$ (dry basis). Control experiments in the form of open air sun drying of similar quantity of tapioca were also set up and monitored. Graphical plots of moisture content versus drying time, exhibited the characteristic moisture desorption curve, characterized by initial high rate of moisture removal, followed by a slower rate of moisture removal. It was observed from drying rate curves plotted using the drying data, that the drying of the tapioca took place entirely in the falling rate period. The drying rate of the tapioca varied with the different combinations of velocity and drying layer thickness. The drying rate of the tapioca increased with increase in the air flow velocity until velocity of $2.5 \mathrm{~m} / \mathrm{s}$; beyond this velocity the drying rate reduced slightly. Also the drying rate of tapioca decreased with increase in drying layer thickness. A maximum drying rate of $39.2 \% / h r$ was obtained during the experiment. The maximum system drying efficiency of the dryer was determined as $47.14 \%$, while the maximum dryer pick-up efficiency of 50\% was determined during the drying test.
\end{abstract}

Keywords: Air Flow Velocity, Drying Rate, Forced Convection, Layer Thickness, Moisture Content, Solar Dryer

\section{INTRODUCTION}

Drying is one of the oldest and important method of food preservation, practiced by humans (Midilli et al., 2002; Sacilik, 2007). The main purpose of drying agricultural materials is to provide longer periods of storage, minimize packaging requirements and reduce transportation weights and costs. Over the years, conventional energy sources like fossil fuel, electricity, and biomass sources had been used as energy sources for heat generation and fan operation in dryers. However, these energy sources are either very costly or non-renewable in nature. The solar energy is fast becoming an alternative source of energy, because of high rate of depletion of the conventional energy sources. It has many advantages over other alternative energy sources, because of its relative abundance, low cost, inexhaustible nature and zero pollution.

Nigeria is the largest producer of cassava in the world (FA0, 1985; 2012), with over 14 million metric tonnes produced in 1985 to over 40 million metric tonnes produced in 2010 . Cassava noodle (tapioca) is a cassava-by product, that is popular and relished by the Eastern and Southern Nigerians. Tapioca is normally produced in two types. The first type is in the form of long thread-like strands (Figure 1a), which is normally dried and preserved (stored). This type is normally sold in the market in the dried form. The second type is in the form of rectangular-shaped flakes (Figure 1b), which is normally sold in the fresh form. This second type is normally eaten in the fresh form with coconut and peanuts, as a local snack. Also the dried tapioca are usually soaked in water and eaten with or without coconut or peanuts as snack (Ihekoronye and Ngoddy, 1985). The softened tapioca also known locally as abacha, cooked with vegetable, palm oil, fish and other food seasoners is known as local (African) salad. The thread-like form of tapioca was used in this research.

Freshly produced tapioca normally have moisture content range of $65 \%$ to $90 \%$ (wet basis), and have safe storage moisture content of $8 \%$ (wet basis). This therefore implies that a reasonable quantity of heat energy should be developed by a dryer, for the drying of tapioca within the desired time. Quick drying of tapioca is advantageous in the sense that risks of contamination and mould growth are minimized. Also, drying and ensiling have been found to be effective ways of reducing the toxicity of cassava products (Phuc et al., 2000; Kajuna et al., 2001). Tapioca strands are normally dried using direct sun method and heat from the fire place. 


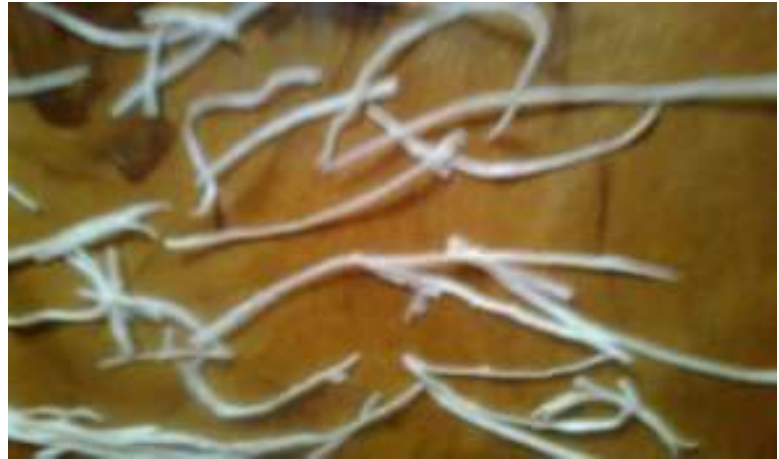

Fig 1(a): Thread-like form of tapioca

These methods are associated with slow rate of drying, exposure of the dried materials to the attack of insects and rodents, and the occasional charring of the materials in the presence of excessive and uncontrolled sun's radiation and heat source. The traditional sun drying of tapioca normally takes an average of 4 to 5 days to complete. Several research works on thin-layer drying kinetics of some cassava byproducts and other agricultural materials are reported in the literature. However, no research work on thin-layer solar drying kinetics for cassava noodles (tapioca) is contained in the literature. Therefore the objectives of this work are (i) to develop an effective solar drying system and (ii) to it to determine the drying kinetics of tapioca.

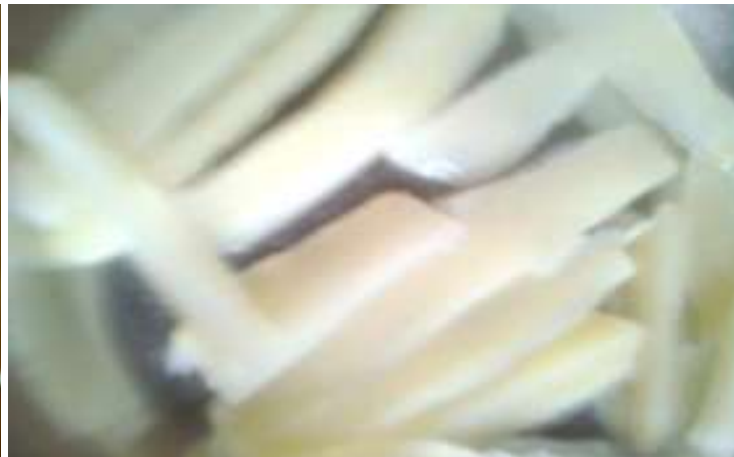

Fig 1(b): Rectangular-shaped form of tapioca

\section{MATERIALS AND METHODS}

\subsection{Description of the Equipment}

The dryer used for the experiment is a forced convection integral type flat plate solar collector (Figure 2). It consists of a solar collector chamber and dryer cabinet both of which were integrated into one unit, fan/blower unit, heat storage unit and chimney.

The solar collector chamber consists of a wooden box of rectangular cross-section, having a length of $1.15 \mathrm{~m}$ and width of $0.75 \mathrm{~m}$, thus giving a cross-sectional area of 0.86 $\mathrm{m}^{2}$. The top of the collector chamber was titled at an angle of $5^{0} 29^{\prime}$ which is the latitude of Owerri. The top of this section was covered with a plain glass, which acts as the glazing material.

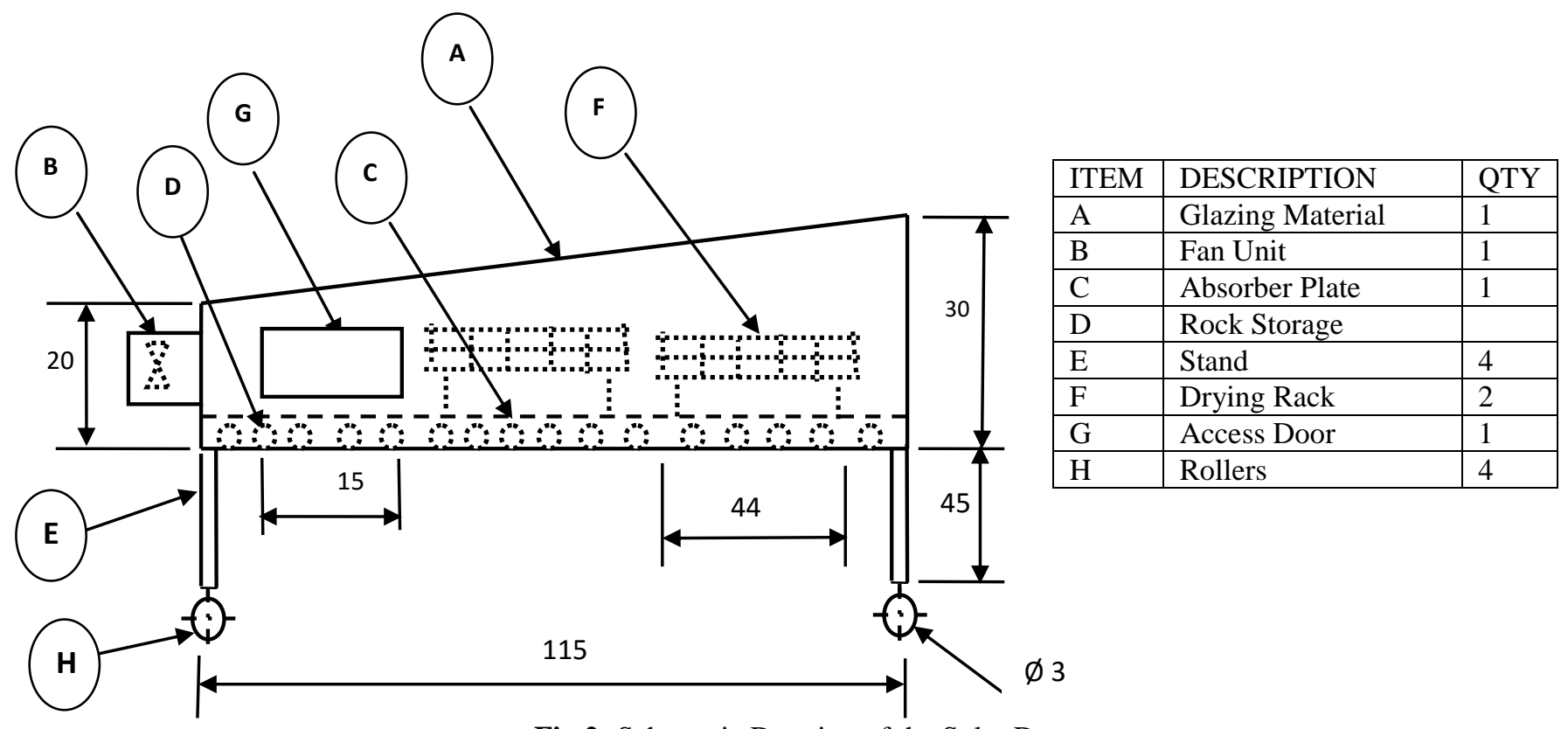

Fig 2: Schematic Drawing of the Solar Dryer

The base of this unit was lined with a layer of dark painted pebbles, which act as a thermal storage unit. A galvanized steel plate with the same dimensions as the collector area and painted dull black was used as an absorber plate. This absorber plate overlay the thermal storage unit. The solar collector has a hole of diameter $15 \mathrm{~cm}$ at the entrance, used for mounting the fan unit. Also a hole of dimensions $8 \mathrm{~cm} \mathrm{x}$
$8 \mathrm{~cm}$, drilled at the exit point, serves as the exit for exhaust air. It also has two access doors used to control the operations.

The drying chamber consists of two racks, each containing two trays of dimensions 0.44 m length $\times 0.44$ m width and depth of $0.04 \mathrm{~m}$. Each of the racks was supported by a 
wooden stand. The outer part of the dryer was painted dull black while the interior sides were lined with aluminum foil, so as to enhance reflectivity of heat inside the dryer chamber. Axial flow fan was used in the solar dryer. The fan was equipped with a speed regulator which helped to regulate the fan speed (air flow velocity). The fan was fixed at the front of a short cylindrical pipe of diameter $15 \mathrm{~cm}$, and length $5 \mathrm{~cm}$, positioned at the entrance of the dryer. The fan was powered by a 20 watts capacity solar panel that was connected to 12 volts, $5 \mathrm{Amps}$, D.C battery for power storage.

\subsection{Experimental Test Using the Solar Dryer}

\subsubsection{Materials and Instrumentation}

The materials and instrumentation used for the drying test include: fresh samples of cassava noodles (tapioca), wet and dry bulb thermometer, digital hygrometer, digital weighing balance, electric oven, digital air flow meter, hand-held pyranometer, and stop clock.

\subsubsection{Sample Preparation}

Large quantities of freshly prepared tapioca were purchased from the Owerri main market. These tapioca samples which were processed from the same variety of cassava tubers (NR 8082 ) have an average moisture content of $297 \%(\mathrm{db})$. The tapioca samples, with thicknesses ranging from 0.21 to 0.26 $\mathrm{cm}$ with average value of $0.24 \mathrm{~cm}$, have an average length of $8 \mathrm{~cm}$ and width of $0.3 \mathrm{~cm}$.

\subsubsection{Procedure for the Experimental Test}

The experiment was designed to be in the form of a $3 \times 2$ factorial with 3 replications, in completely randomized design (CRD). The factors are air flow velocity with levels: $1.5,2.5$, and $3.5 \mathrm{~m} / \mathrm{s}$; and layer thickness of tapioca with levels 0.48 and $0.72 \mathrm{~cm}$. At the beginning of the experiment, the flat plate solar dryer was positioned in an open place, away from tall trees and buildings, so as to minimize the effect of shading. The solar dryer was aligned in the NorthSouth axis, and positioned to face South as recommended in literature (Duffie and Beckman, 2006; Tiwari, 2012). This was to maximize the solar radiation falling on the surface of the dryer.

The dryer was allowed to run for 30 minutes under no load, before the commencement of drying tests. This enabled the dryer to attain equilibrium conditions. The mass of the tapioca samples corresponding to the layer thicknesses of $0.48 \mathrm{~cm}$ and $0.72 \mathrm{~cm}$ were weighed using the digital weighing balance (OHAUS) of capacity $4.1 \mathrm{~kg}$ and sensitivity of $0.01 \mathrm{~g}$. The weighed tapioca samples were then

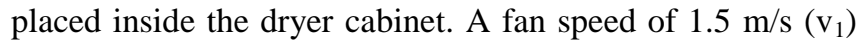
was selected. The layer thicknesses of 0.48 and $0.72 \mathrm{~cm}$ were achieved by using two layers $(0.48 \mathrm{~cm})$ and three layers $(0.72 \mathrm{~cm})$ of the tapioca samples respectively. ASAE, (1999) states that a thin - layer is a layer that is fully exposed to drying air, and should not exceed three layers of particles (materials) for forced convection drying, at air velocity not less than $0.3 \mathrm{~m} / \mathrm{s}$. A given portion of the tapioca samples in the dryer cabinet was collected and weighed, to determine the initial mass of the sample. This given portion was then put back into a smaller (observation) tray, inside the dryer cabinet. A similar mass of the tapioca samples was placed in a drying tray, similar in dimensions to that of the solar dryer, and dried in the open sun as a comparison treatment in the experiment. The masses of both the tapioca samples at both the dryer and the ambient air, were determined at hourly intervals. Also the dry bulb temperature and relative humidity of the dryer were determined at hourly intervals, using the digital hygrometer; and the wet and dry bulb temperatures of the ambient air were determined at hourly intervals during the drying test. A hand-held pyranometer (model: 4890.20; Frederiksen) was used to measure the insolation falling on the surface of the solar dryer at hourly intervals.

The drying process continued until equilibrium moisture content of the tapioca at the given drying conditions was reached. This point was characterized by a constant mass recorded for two consecutive measurements of mass during the drying process. At the end of the drying experiment, the marked portion of the sample was oven dried at a temperature of $100^{\circ} \mathrm{C}$ for 8 hours to obtain the oven dried mass, as recommended in literature (Kajuna et al., 2001). The experimental tests for the thin-layer solar drying of tapioca were done at Federal University of Technology, Owerri, between the months of September to November, 2014.

The moisture contents (dry basis) M (db) of the tapioca were determined using Equation (1)

$$
M(d b)=\frac{m_{w p}-m_{d p}}{m_{d p}}(100 \%)
$$

Where $\mathrm{M}=$ moisture content of materials $\left(\mathrm{g} \mathrm{H}_{2} \mathrm{O} / 100 \mathrm{~g}\right.$ dry matter)

$\mathrm{m}_{\mathrm{wp}}=$ mass of wet product $(\mathrm{g})$

$\mathrm{m}_{\mathrm{dp}}=$ mass of dry product $(\mathrm{g})$

\subsection{Determination of Drying Kinetics of Tapioca}

Drying kinetics like system drying efficiency, pick-up efficiency, and drying rate of tapioca for each observation (drying experiment) were determined and tabulated. The drying rate $\left(R_{d}\right)$, which is the rate of change of moisture content with time, was determined according to (Doymaz, 2013) and expressed in Equation (2).

$$
R_{d}=\frac{m_{w}}{t}=\frac{M_{i}-M_{f}}{t}
$$

Where $\mathrm{M}_{\mathrm{i}}=$ initial moisture content of the sample ( $\mathrm{g}$ $\mathrm{H}_{2} \mathrm{O} / 100$ g dry matter)

$\mathrm{M}_{\mathrm{f}}=$ final moisture content of the sample $\left(\mathrm{g} \mathrm{H}_{2} \mathrm{O} / 100 \mathrm{~g}\right.$ dry matter)

$\mathrm{m}_{\mathrm{w}}=$ mass of water removed during the drying period $\mathrm{t}=$ drying time (hours) 
The system drying efficiency $\left(\eta_{\mathrm{d}}\right)$ was calculated using equation (3) as given by Komolafe and Osunde, (2005).

$$
\eta_{d}=\frac{m_{w} L_{v}}{I_{H} A_{c} t}
$$

Where $\mathrm{I}_{\mathrm{H}}=$ insolation falling on a horizontal surface. All the other parameters are as previously defined.

The pick-up efficiency $\left(\eta_{\mathrm{p}}\right)$ was calculated using Equation (4) as given by Brenndorfer et al. (1987).

$$
\eta_{p}=\frac{H_{o}-H_{i}}{H_{a s}-H_{i}}
$$

Where $\mathrm{H}_{\mathrm{o}}=$ absolute humidity of air leaving the drying chamber

\begin{tabular}{|c|c|c|c|c|c|c|c|c|}
\hline \multirow{3}{*}{\begin{tabular}{|l|} 
B \\
Method \\
V \\
\end{tabular}} & \multicolumn{4}{|l|}{0.48} & \multicolumn{4}{|l|}{0.72} \\
\hline & \multicolumn{3}{|c|}{ Dryer } & \multirow{2}{*}{$\begin{array}{l}\text { Open sun } \\
9.5 \\
\end{array}$} & \multicolumn{3}{|l|}{ Dryer } & \multirow{2}{*}{$\begin{array}{l}\text { Open sun } \\
9.8 \\
\end{array}$} \\
\hline & 1.5 & 2.5 & 3.5 & & 1.5 & 2.5 & 3.5 & \\
\hline TIME(hrs) & \multicolumn{8}{|c|}{ MOISTURE CONTENT (\%, dry basis) } \\
\hline 0 & 297 & 297 & 297 & 297 & 297 & 297 & 297 & 297 \\
\hline 0.5 & 223 & 209 & 227 & 247 & 270 & 269 & 273 & 294 \\
\hline 1 & 204 & 178 & 193 & 222 & 251 & 257 & 247 & 278 \\
\hline 2 & 159 & 118 & 147 & 204 & 217 & 214 & 215 & 254 \\
\hline 3 & 128 & 90 & 123 & 179 & 193 & 189 & 191 & 229 \\
\hline 4 & 98 & 61 & 94 & 147 & 161 & 148 & 157 & 197 \\
\hline 5 & 72 & 34 & 71 & 139 & 127 & 111 & 115 & 168 \\
\hline 6 & 40 & 18 & 52 & 126 & 106 & 78 & 81 & 154 \\
\hline 7 & 22 & 11 & 36 & 81 & 74 & 59 & 60 & 125 \\
\hline 7.5 & & 9.8 & & & & 34 & & \\
\hline 8 & 14 & & 21 & 64 & 37 & 14 & 39 & 93 \\
\hline 9 & 9.8 & & 15 & 48 & 17 & 9.8 & 23 & 64 \\
\hline 9.5 & & & & & 12 & & & 55 \\
\hline 10 & & & 11 & 29 & 9.8 & & 17 & 40 \\
\hline 10.5 & & & 9.8 & & & & & \\
\hline 11 & & & & 22 & & & 11 & 29 \\
\hline 11.5 & & & & & & & 9.8 & \\
\hline 12 & & & & 15 & & & & 22 \\
\hline 13 & & & & 11 & & & & 15 \\
\hline 13.5 & & & & 9.8 & & & & \\
\hline 14 & & & & & & & & 10 \\
\hline 15 & & & & & & & & 9.8 \\
\hline $\begin{array}{ll}\begin{array}{l}\text { Average } \\
\text { drying } \\
(\% / h r)\end{array} & \\
\end{array}$ & 31.9 & 39.2 & 27.35 & 21.27 & 27.81 & 31.9 & 24.98 & 19.15 \\
\hline
\end{tabular}

Table 1: Mean Values of Moisture Contents for Different Drying Times of the Experiment

$\mathrm{B}=$ layer thickness of tapioca $(\mathrm{cm}), \mathrm{V}=$ air flow velocity $(\mathrm{m} / \mathrm{s})$
$\mathrm{H}_{\mathrm{i}}=$ absolute humidity of air entering the drying chamber

$\mathrm{H}_{\mathrm{as}}=$ adiabatic saturation humidity of air entering the drying chamber

\section{RESULTS}

\subsection{Results Obtained for Thin-Layer Solar Drying of Tapioca}

The results of thin-layer solar drying of tapioca are summarized in Table (1), and Figures (3), (4) and (5); while the summary of values of temperature, relative humidity, and insolation are given in Table (2). The results of the analysis of variance on the effect of air velocity and layer thickness on thin-layer drying of tapioca are summarized in Table (3). 
Table 2: Summary of Temperature, Relative Humidity and Insolation during Drying Compared to Open Air Sun Drying

\begin{tabular}{|c|c|c|c|c|c|c|c|c|c|c|}
\hline \multirow[t]{2}{*}{$\begin{array}{l}\text { Drying } \\
\text { Method }\end{array}$} & \multirow[t]{2}{*}{ B } & \multirow[t]{2}{*}{$\mathbf{V}$} & \multicolumn{3}{|c|}{ Temperature $\left({ }^{0} \mathrm{C}\right)$} & \multicolumn{3}{|c|}{ Relative Humidity (\%) } & \multirow[t]{2}{*}{$\begin{array}{l}\text { Insolation } \\
\left(\mathrm{W} / \mathbf{m}^{2}\right)\end{array}$} & \multirow{2}{*}{$\begin{array}{l}\text { Drying } \\
\text { Rate } \\
(\% / h r)\end{array}$} \\
\hline & & & dryer & ambient & $\Delta \mathbf{T}_{\mathbf{d a}}$ & dryer & ambient & $\Delta \mathbf{R H}$ & & \\
\hline \multirow[t]{6}{*}{ dryer } & \multirow{3}{*}{0.48} & 1.5 & 49.47 & 31.6 & 17.87 & 30.38 & 73.6 & 43.22 & 433.8 & 31.9 \\
\hline & & 2.5 & 50.41 & 32.25 & 18.16 & 23.5 & 67.5 & 44 & 468.9 & 39.2 \\
\hline & & 3.5 & 49.02 & 32.2 & 16.82 & 26.9 & 65.67 & 38.77 & 464.8 & 27.35 \\
\hline & \multirow{3}{*}{0.72} & 1.5 & 49.37 & 32.62 & 16.75 & 31.6 & 69.3 & 37.7 & 498.6 & 27.81 \\
\hline & & 2.5 & 53.59 & 33.5 & 20.09 & 25.25 & 63.4 & 38.15 & 521.2 & 31.9 \\
\hline & & 3.5 & 52.86 & 33.25 & 19.61 & 27.1 & 67.1 & 40 & 495.5 & 24.98 \\
\hline \multirow[t]{2}{*}{ Sun drying } & 0.48 & 0.95 & 49.63 & 32 & 0 & 26.93 & 68.92 & 0 & 455.83 & 21.27 \\
\hline & 0.72 & 0.98 & 51.94 & 33.12 & 0 & 27.98 & 66.6 & 0 & 505.1 & 19.15 \\
\hline
\end{tabular}

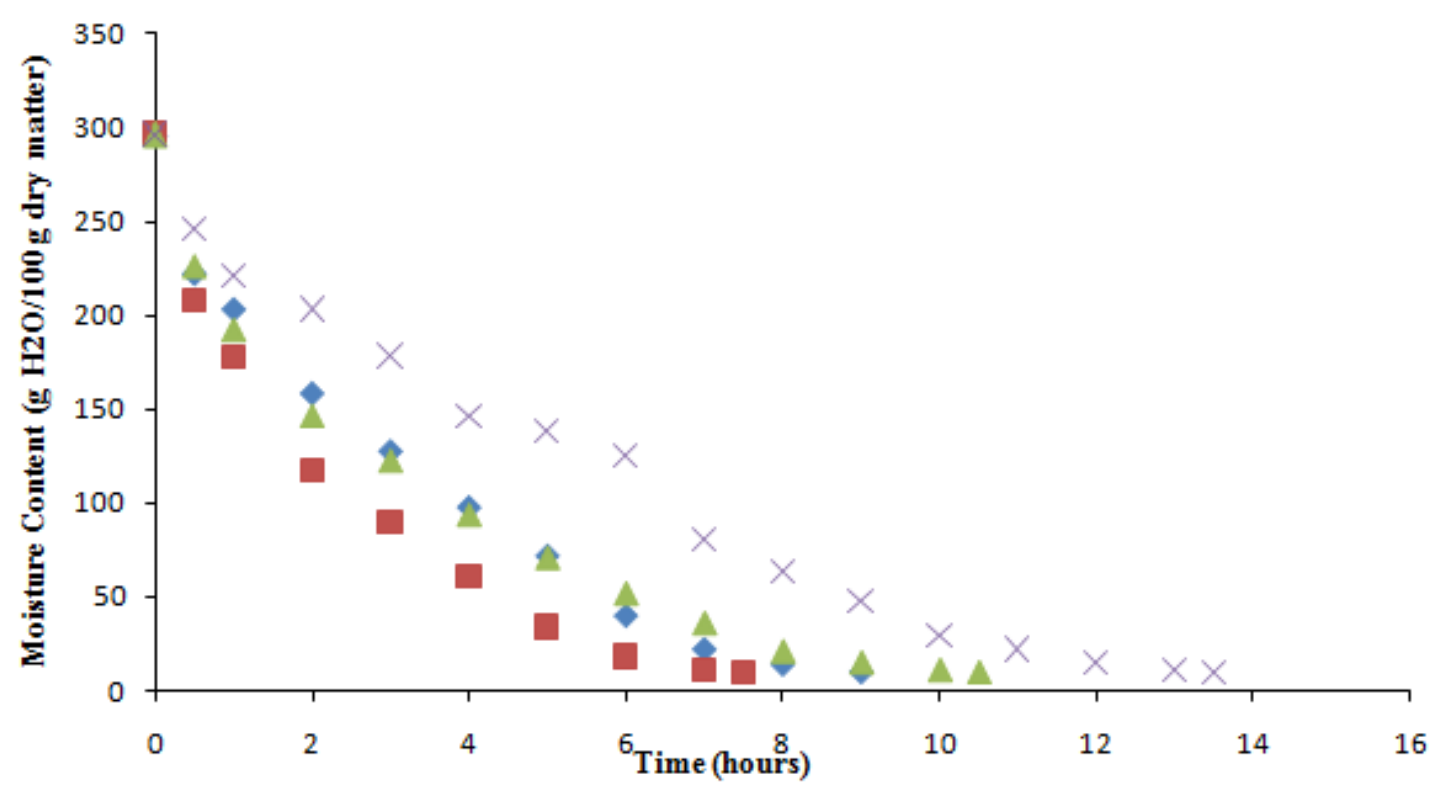

Fig 3: Drying Curve for Layer thickness of $0.48 \mathrm{~cm}$

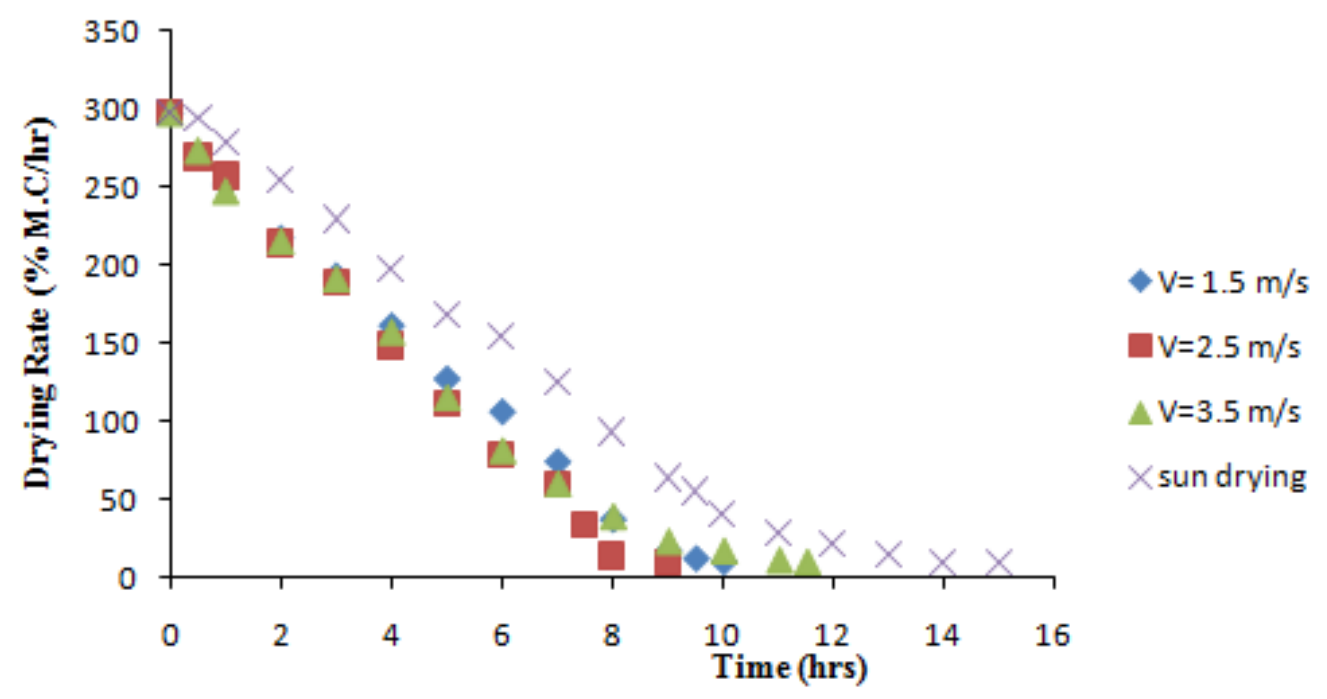

Fig 4: Drying Curve for Layer Thickness of $0.72 \mathrm{~cm}$ 


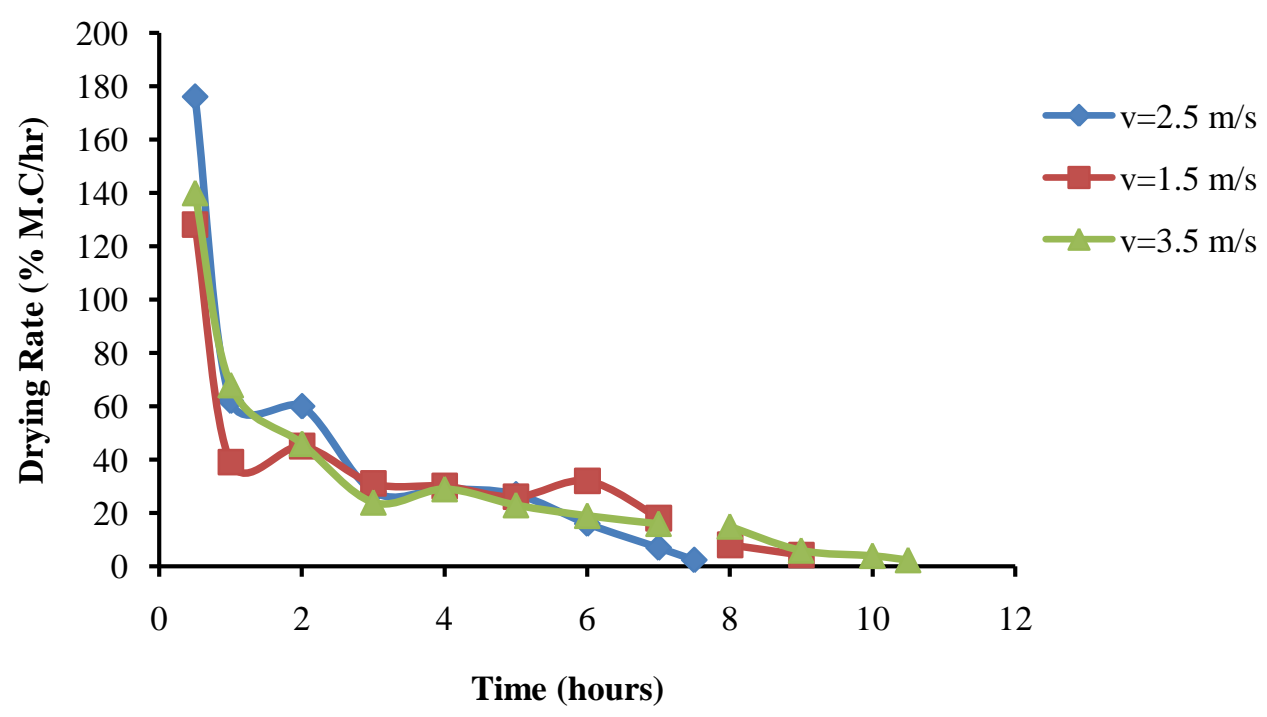

Fig 5: Drying Rate Curve for Tapioca at Varying Times for Layer Thickness of $0.48 \mathrm{~cm}$

Table 3: Summary of Analysis of Variance on the Effects of Velocity and Layer Thickness on Drying Rate of Tapioca.

\begin{tabular}{|l|l|l|l|l|l|}
\hline Source of Variation & df & Sum of squares & Mean square & Fcal & Ftab \\
\hline Treatment & 5 & 381.93 & $76.39^{* *}$ & 146.3 & 5.06 \\
\hline V & 2 & 268.37 & $134.19^{* *}$ & 257.06 & 6.93 \\
\hline B & 1 & 94.76 & $94.76^{* *}$ & 181.53 & 9.33 \\
\hline VB Interaction & 2 & 18.8 & $9.4 * *$ & 18.01 & 6.93 \\
\hline Error & 12 & 6.26 & 0.522 & - & - \\
\hline Total & 17 & 388.19 & - & - & - \\
\hline
\end{tabular}

** Highly significant at $1 \%$ level of probability

\subsection{Results Obtained for System Drying Efficiency of the Dryer}

The system drying efficiency of the solar dryer was determined from Equation (3). The $\mathrm{m}_{\mathrm{w}}$ values of $2154 \mathrm{~g}$ and $2767.65 \mathrm{~g}$ were obtained for layer thicknesses of $0.48 \mathrm{~cm}$ and $0.72 \mathrm{~cm}$ respectively. Since the average dryer temperature for all the experiments is approximately $50^{0} \mathrm{C}$, the latent heat of vaporization $\left(\mathrm{L}_{\mathrm{v}}\right)$ at a temperature of $50^{\circ} \mathrm{C}$ was used for the computation, and this has a value of 2383 $\mathrm{J} / \mathrm{kg} \mathrm{K}$. the other parameters in Equation (3) were given as follows: $\mathrm{Ac}=0.86 \mathrm{~m}^{2}$, the drying times $(\mathrm{t})$ and values of insolation were given in Tables (1) and (2). Table (4) shows the values of the system drying efficiencies corresponding to each treatment combination of the drying experiment for tapioca.

Table 4: System Drying Efficiencies for the Different Treatment Combinations of the Drying of Tapioca

\begin{tabular}{|c|c|c|c|c|c|c|}
\hline $\mathbf{B}$ & \multicolumn{3}{|l|}{0.48} & \multicolumn{3}{|l|}{0.72} \\
\hline \multirow[t]{3}{*}{$\mathbf{V}$} & 1.5 & 2.5 & 3.5 & 1.5 & 2.5 & 3.5 \\
\hline & \multicolumn{6}{|c|}{ Values of system drying efficiency (\%) } \\
\hline & 42.50 & 47.14 & 33.97 & 40.69 & 45.41 & 37.38 \\
\hline
\end{tabular}

$\mathrm{B}=$ drying layer thickness $(\mathrm{cm}), \mathrm{V}=$ air flow velocity $(\mathrm{m} / \mathrm{s}), \mathrm{M}=$ initial moisture content $(\%)$

\subsection{Results Obtained for Pick-up Efficiency of the} Dryer

The pick-up efficiency for the solar drying of tapioca was determined using Equation (4). The values of absolute humidities (hi, ho, has) were determined from the ASHRE psychrometric chart and given in Table (5). The results of the pick-up efficiencies of the solar dryer, determined for the drying of tapioca are summarized in Table (6). 
Table 5: Values of Absolute Humidities $\left(h_{i}, h_{o}, h_{a s}\right)$, obtained from Psychrometric chart used in the determination of pick-up efficiencies of the solar Dryer

\begin{tabular}{|l|l|l|l|l|l|l|}
\hline $\mathbf{B}$ & 0.48 & \multicolumn{6}{l|}{} & 0.72 & \\
\hline $\mathbf{V}$ & 1.5 & 2.5 & 3.5 & 1.5 & 2.5 & 3.5 \\
\hline $\mathrm{h}_{\mathrm{i}}$ & 0.018 & 0.014 & 0.016 & 0.020 & 0.018 & 0.021 \\
\hline $\mathrm{h}_{0}$ & 0.025 & 0.022 & 0.021 & 0.025 & 0.024 & 0.024 \\
\hline $\mathrm{h}_{\mathrm{as}}$ & 0.032 & 0.030 & 0.029 & 0.032 & 0.031 & 0.031 \\
\hline
\end{tabular}

$\mathrm{B}=$ drying layer thickness $(\mathrm{cm}), \mathrm{V}=$ air flow velocity $(\mathrm{m} / \mathrm{s})$

Table 6: Pick-up Efficiencies Obtained for Different Velocities and Thicknesses for the Drying of Tapioca

\begin{tabular}{|l|l|l|l|}
\hline & \multicolumn{3}{|l|}{ Pick-up efficiencies for the various treatments } \\
\hline B & $\mathbf{V = 1 . 5}$ & $\mathbf{V = 2 . 5}$ & $\mathbf{V}=\mathbf{3 . 5}$ \\
\hline $\mathbf{0 . 4 8}$ & 42.9 & 50 & 38.5 \\
\hline $\mathbf{0 . 7 2}$ & 41.7 & 46.2 & 30 \\
\hline
\end{tabular}

$\mathrm{B}=$ thickness of drying layer $(\mathrm{cm}), \mathrm{V}=$ air flow velocity $(\mathrm{m} / \mathrm{s})$

\section{DISCUSSION}

It was observed from Table (1), that the moisture content of the tapioca decreased with drying time until the equilibrium moisture content was reached. It was also observed that the drying time for the tapioca samples varied with the different treatment combinations of air flow velocity, thickness of layer, and drying with the open air (Table 1). In each of these tests, tapioca samples at initial moisture content of $297 \%$ (dry basis) were dried to equilibrium moisture content of $9.8 \%$ (dry basis). The shortest drying time of 7.5 hours was recorded for the tapioca samples at air flow velocity of $2.5 \mathrm{~m} / \mathrm{s}$ and layer thickness of $0.48 \mathrm{~cm}$; while the longest drying time of 11.5 hours was recorded for samples at velocity of $3.5 \mathrm{~m} / \mathrm{s}$ and layer thickness of $0.72 \mathrm{~cm}$. It was observed that the samples in the solar dryer, dried about $12 / 3$ to 2 times faster than the tapioca samples dried in the open air. This observation is in line with previous research findings in related work (Ezeanya et al.,2012; Komolafe and Osunde, 2005). Also the color of the samples dried inside the dryer was milky white, while the color of the samples dried under ambient conditions was dull white to whitish yellow. This therefore implies that the solar dryer produced better quality drying than open air sun drying. Table (2) shows the summary of the temperature, relative humidity, and insolation obtained during the thin-layer solar drying of tapioca. From Table (2), it was observed that the average values of temperature and relative humidity for both the dryer and ambient air varied with the different treatment combinations (drying conditions). The average dryer temperatures ranged from 49.02 to $53.59^{\circ} \mathrm{C}$, with an average value of $50.79^{\circ} \mathrm{C}$; while the average relative humidity values ranged from $23.5 \%$ to $31.6 \%$, with an average value of $27.45 \%$. The study also revealed that the drying rate of the tapioca samples varied with the different treatment combinations of the experiment as shown in Tables (1) and (2).

The fastest drying rate of $39.2 \% / \mathrm{hr}$, was recorded for tapioca samples at velocity of $2.5 \mathrm{~m} / \mathrm{s}$ and layer thickness of $0.48 \mathrm{~cm}$; and the lowest drying rate of $24.98 \% / \mathrm{hr}$ was recorded for tapioca samples at velocity of $3.5 \mathrm{~m} / \mathrm{s}$ and layer thickness of $0.72 \mathrm{~cm}$.
Figures (3) and (4) show the drying curves (plots of moisture contents versus time) for the layer thicknesses, and different air flow velocities used for the drying experiment. The curves sloped downwards from left to right, showing that moisture content decreased with increase in drying time. Figures (3) and (4) also show that the time taken to dry the tapioca to the equilibrium moisture content of $9.8 \%$ (dry basis), varied with the different air flow velocities and layer thicknesses of the tapioca.

\subsection{Effect of Air-Flow Velocity on the Drying Rate of Tapioca}

Tables (1) and (2); and Figures (3) and (4) show the effect of the air-flow velocity on the drying rate of tapioca. It is evident from these tables and figures that the drying rate increased with increase in air flow velocity, for air-flow velocities of $1.5 \mathrm{~m} / \mathrm{s}$ to $2.5 \mathrm{~m} / \mathrm{s}$; which agrees with similar research findings reported by Saeed (2010) and Iguaz et al (2003). This trend may be as a result of the fact that higher velocities improve the rate of moisture transfer (effective moisture diffusivity) from the product being dried, thus resulting in faster rate of drying. However, increasing the air-flow velocity to $3.5 \mathrm{~m} / \mathrm{s}$ extended the drying time thus reducing the drying rate (Tables 1 and 2). This development may be attributed to the quick formation of hard layer (case hardening) at relatively high temperature and velocity. This layer increased resistance to transport (diffusion) of moisture from the tissues of the dried product, thus preventing water vapor concentration from reaching equilibrium in time. This phenomenon was also reported by Togrul and Pehlivan (2002) and Saeed (2010). The analysis of variance summarized in Table (3), shows that the effect of air velocity on thin-layer solar drying of tapioca was highly significant at $1 \%$ level of probability.

\subsection{Effect of Layer Thickness on Drying Rate of}

\section{Tapioca}

The experimental data samples in Tables (1) and (2), and the drying curves in Figures (3) and (4) show that the drying time generally increased with increasing layer thickness of the tapioca samples, for samples at the same velocity and 
initial moisture content. Thus drying rates were higher for samples dried at layer thickness of $0.48 \mathrm{~cm}$ than for the samples dried at $0.72 \mathrm{~cm}$. This trend in the drying characteristics of tapioca agrees with similar research findings in the literature, reported for cassava chips, apple (var Golab), and eggplant slices (Kajuna et al., 2001; Meisame Ail and Rafiee, 2009; Ertekin and Yalidz, 2004). This behavior may be attributed to the fact that the thicker the layers of a moist material are, the higher the amount of water it contains and thus for a fixed quantity of heat energy available for the drying process, the longer time required to remove the water from such material. From Table (3), it was evident that the effect of layer thickness on the thin-layer solar drying of tapioca was highly significant at $1 \%$ level of probability.

Figure (5) is a graphical plot, showing the variation of the drying rates of tapioca with drying time, for the tapioca samples dried at thicknesses of $0.48 \mathrm{~cm}$. From these plots (Figures 5), it was evident that the drying rate was highest at the beginning of the drying experiment, and gradually reduced towards the end of the drying experiment. This implies that the drying of the tapioca samples took place entirely in the falling rate period of drying.

\subsection{Effects of Air Velocity and Layer Thickness on}

\section{System Drying Efficiency}

From Table (4), it was observed that the system drying efficiencies varied with the different treatment combinations of the experiment. The efficiencies ranged from a maximum mean value of $47.14 \%$ for tapioca samples dried at layer thickness of $0.48 \mathrm{~cm}$ and velocity of $2.5 \mathrm{~m} / \mathrm{s}$; to a minimum mean value of $33.97 \%$ for tapioca samples dried at layer thickness of $0.48 \mathrm{~cm}$ and velocity of $3.5 \mathrm{~m} / \mathrm{s}$. These efficiencies are within the range reported for solar drying of related agricultural products like tomato and cassava chips (Komolafe and Osunde, 2005; Aliyu and Jubril, 2009). These values of the system drying efficiency imply that the dryer was able to convert a reasonable part of the solar radiation incident on its surface to heat energy used in the drying of the tapioca.

\subsection{Effects of Air Velocity and Layer Thickness on}

\section{Pick-up Efficiency}

It is evident from Table (6) that the pick-up efficiencies varied with the different treatments of the experiment. The maximum pick-up efficiency of $50 \%$ was determined for layer thickness of $0.48 \mathrm{~cm}$ and air flow velocity of $2.5 \mathrm{~m} / \mathrm{s}$; while the least pick-up efficiency of $30 \%$ was determined for layer thickness of $0.72 \mathrm{~cm}$ and air flow velocity of 3.5 $\mathrm{m} / \mathrm{s}$. The reasonable high value of the pick-up efficiency indicates that the tapioca samples were able to absorb reasonable quantity of heat from the drying air.

\section{CONCLUSION}

Thin-layer solar drying kinetics of tapioca was studied. The summary of the results show that the drying of tapioca occurred entirely in the falling rate drying period; and the drying rate of tapioca varied with the air flow velocity and the layer thickness of the tapioca.

A maximum drying rate of $39.2 \% / \mathrm{hr}$ was obtained for the tapioca samples dried at air flow velocity of $2.5 \mathrm{~m} / \mathrm{s}$ and layer thickness of $0.48 \mathrm{~cm}$; while the lowest drying rate of $33.97 \% / \mathrm{hr}$ was obtained for the tapioca samples dried at air flow velocity of $3.5 \mathrm{~m} / \mathrm{s}$, and layer thickness of $0.72 \mathrm{~cm}$ during the experiment. The study also revealed that the solar dried tapioca samples dried about $1 \frac{2 / 3}{3}$ to 2 times faster than the tapioca samples dried under ambient conditions. A maximum system drying efficiency of $47.14 \%$ was obtained for tapioca samples dried at layer thickness of $0.48 \mathrm{~cm}$ and air velocity of $2.5 \mathrm{~m} / \mathrm{s}$. Also the maximum pick-up efficiency of $50 \%$ was obtained for tapioca samples dried at layer thickness of $0.48 \mathrm{~cm}$ and air flow velocity of $2.5 \mathrm{~m} / \mathrm{s}$.

\section{REFERENCES}

[1] Aliyu, A.B and H. Jibril, 2009. Utilization of green house effect for solar drying of cassava chips. International J. Physical Sci., 4(11): 615-622

[2] ASAE (1999). Thin - layer drying of crops and grains. American Society of Agricultural Engineers' Standards: 581-583

[3] Brenndorfer, B., L. Kennedy., S.O. Oswin-Bateman., D.S. Trim., G.C Mrema., and C. Wereko-Brobby, 1987. Solar dryers - their role in post-harvest processing. Commonwealth Secretariat Publications. London.

[4] Doymaz, I., 2013. Determination of infrared drying characteristics and modeling of drying Behavior of carrot pomace. J. Agric. Sci, 19(2013): 44 - 53.

[5] Duffie, J. A and W. A. Beckman, 2006. Solar engineering of thermal processes, third edition. John Wiley and Sons Inc. New Jersey. USA.

[6] Ertekin, C. and O. Yaldiz, 2004. Drying of eggplant and selection of a suitable thin layer drying model. J. Food Eng., 6: 349-359.

[7] Ezeanya, N.C., K.N. Nwaigwe and P.E. Ugwuoke, 2012. Analysis of the effects of a flat Plate solar dryer geometry on the drying rate of agricultural seeds. Asian J. Agric. Sci., 4(5): 333-336.

[8] FAO, 1985. Year production Book, Rome, Italy. Vol 39.

[9] FAO, 2012. Food Outlook. Global market analysis. November, 2012. ISSN: $0251-1959$.

[10] Iguaz, A., M.B. San Martin., J.I. Mate., T. Fernandez and P. Fernandez, 2003. modeling of effective moisture diffusivity of rough rice (Lido cultivar) at low drying temperatures. J. Food Eng., 59: 253-258.

[11] Ihekoronye, I. A and P. O Ngoddy, 1985. Integrated Food Science and Technology for the tropics. Macmillan Educ. Ltd. London and Oxford $1^{\text {st }}$ edition. pp. 172 - 190, 298-352.

[12] Kajuna, S.T.A.R., V.C.K. Silayo., A. Mkenda and P.J.J. Makungu, 2001. Thin layer drying of diced cassava roots. African J. Sci. and Tech. Science and Engineering series, 2 (2): $94-100$. 
[13] Komolafe, G.O and Z.D. Osunde, 2005. Design and performance evaluation of small size natural convection solar vegetable dryer. Proceedings of NIAE, 27: $215-221$.

[14] Meisami-asl, E and S. Rafiee, 2009. Mathematical modeling of kinetics of thin layer drying of Apple (var. Golab). CIGR E journal. Manuscript 1185, vol XI.

[15] idilli, A., H. Kucuk and Z. Yapar, 2002. A new model for single layer drying. Drying Tech., 20: 1503 - 1513

[16] Phuc, B.H.N., Ogle, B and Lindbergh, J.E. (2000). Effect of replacing soybean meal with cassava leaf protein in cassava root meal based diets for growing pigs on digestibility and $\mathrm{N}$ - retention, Animal Feed Science Technology, 83: $223-235$.

[17] Sacilik, K., 2007. Effect of drying methods on thinlayer drying of hull-less seed pumpkin (curcubita pepo L.) J. Food Eng., 79: 23 - 30.

[18] Saeed, I.E., 2010. Solar drying of roselle (Hibiscus Sabdarifa L.) (1): Mathematical modeling, drying experiments, effects of the drying conditions. J. CIGR., $12(3): 115-123$

[19] Tiwari, G. N., 2012. Solar Energy: fundamentals, design, modeling and applications. Narosa Publishing house, PVT Ltd. New Delhi. $9^{\text {th }}$ Edition.

[20] Togrul, I.T and D. Pehlivan, 2002. Mathematical modeling of solar drying of apricots in thin-layers. J. Food Eng., 55(1): 209 - 216. 